Research Journal of Pharmacology 4 (3): 55-59, 2010

ISSN: $1815-9362$

C) Medwell Journals, 2010

\title{
Bioactive Constituents of Conyza floribunda
}

\author{
${ }^{1}$ Silvia Awino Opiyo, ${ }^{1}$ Lawrence Onyango Arot Manguro, \\ ${ }^{1}$ Joseph A. Ogur and ${ }^{2}$ Samuel Otieno Wagai \\ ${ }^{1}$ Department of Chemistry, ${ }^{2}$ Department of Botany, Maseno University, \\ P.O. Box 333, Maseno, Kenya
}

\begin{abstract}
The study describes the antibacterial and antifungal effects of both $\mathrm{CH}_{2} \mathrm{Cl}_{2}$ and $\mathrm{MeOH}$ crude extracts, collected fractions and pure isolates of Conzya floribunda. The antimicrobial activity tests were carried out using agar diffusion method. In vitro tests using $\mathrm{CH}_{2} \mathrm{Cl}_{2}$ and $\mathrm{MeOH}$ extracts of C. floribunda showed antibacterial activities against Streptococcus pneumoniae, Staphylococcus aureus and Escherischia coli and antifungal activities against Candida albicans, Trichophyton mentagrophytes and Microsporum gypsium. The antibacterial and antifungal principles from C. floribunda were found to be (24S)-ethylcholesta-5, 22E, 25-dien3-O- $\beta$-glucoside and cyasterone from methanol extract and 3-oxofriedooleanane and betullinic acid associated with $\mathrm{CH}_{2} \mathrm{Cl}_{2}$ extract. The results of the present study indicate that the plant could be a useful remedy for some of the disease conditions caused by the tested bacteria and fungi and the isolated compounds could be good candidates as phytotherapeutic agents some bacterial and fungal infections.
\end{abstract}

Key words: Conyza floribunda, asteraceae, active principles, antimicrobial activity, bioactive constituents, Kenya

\section{INTRODUCTION}

The genus Conyza (Asteraceae) comprises of about 50 species which are mainly found in tropical and subtropical regions (Agnew and Agnew, 1994; Kokwako, 1976). In Kenya, the genus is represented by 24 species, distributed country wide and one such species is Conyza floribunda. The plant grows up to $3 \mathrm{~m}$ tall when fully mature and is common in wet regions along the road sides, gardens and in disturbed soils within altitudes of 400-2000 m above sea level (Zdero et al., 1990). It is traditionally used for a variety of pharmacological applications including treatment of smallpox, chickenpox, soar throat, ringworm and other skin related diseases, toothache and to stop bleeding from injuries (Pandey et al., 1984).

Previous phytochemical studies on the plant are scarce. However, studies on other related species have lead to the isolation of secondary metabolites, some of which have been reported to exhibit biological activities including anti-inflammatory (Bohlmann and Wagner, 1982; Ahmed et al., 1992; Mata et al., 1997), antitumor (Calzada et al., 2001; Xu et al., 1998) and antioxidants (Picciaroni et al., 2000; De las Heras et al., 1998). In the present study, we report the bioassay guided fractionation of $\mathrm{CH}_{2} \mathrm{Cl}_{2}$ and $\mathrm{MeOH}$ extracts of the whole plant using agar well diffusion method.

\section{MATERIALS AND METHODS}

Instrumental analysis: The UV spectra were run on PYE UNICAM SP8-150 UV/Vis spectrophotometer. IR data were obtained on Perkins-Elmer 600 FTIR series using acetonitrile and $\mathrm{KBr}$ pellet.

The NMR data were measured in $\mathrm{CDCl}_{3}$ and $\mathrm{CDCl}_{3}-\mathrm{DMSO}_{6} \mathrm{~d}_{6}$ on a Brucker NMR Ultrashied TM operating at 500 and $125 \mathrm{MHz}$, respectively. The MS data were obtained on a MAT 8200 A Varian Bremen instrument.

Plant material: Authenticated Conyza floribunda whole plant was collected at Maseno University Botanical garden in June 2005 and a voucher specimen deposited at the National Museum of Kenya (Voucher deposit number: 2005/06/01/SAO/CHEMMK). The whole plant was airdried under shade in the open and reduced to a powder using a Wiley mill.

Preparation of plant extracts: Dry powdered plant material $(2 \mathrm{~kg})$ was sequentially extracted with $\mathrm{CH}_{2} \mathrm{Cl}_{2}(3 \mathrm{~L})$ and $\mathrm{MeOH}(3 \mathrm{~L}$ ) by percolation for 1 week each time, with occasional shaking, thereafter filtered and then concentrated in vacuo to afford 65 and $105 \mathrm{~g}$ of extracts, respectively.

Corresponding Author: Lawrence Onyango Arot Manguro, Department of Chemistry, Maseno University, P.O. Box 333, Maseno, Kenya 
Isolation and identification of compounds from $\mathrm{CH}_{2} \mathrm{Cl}_{2}$ extract: Approximately, $60 \mathrm{~g}$ of the extract was dissolved in small amount of $\mathrm{CH}_{2} \mathrm{Cl}_{2}$ and adsorbed onto silica gel for column chromatography. Fractionation of the extract using gradient of n-hexane-ethyl acetate and $\mathrm{MeOH}$ afforded 300 fractions ( $20 \mathrm{~mL}$ each) whose composition were monitored by TLC using solvent systems n-hexaneEtOAc $(9: 1 ; 4: 1 ; 2: 1)$ and $\mathrm{CH}_{2} \mathrm{Cl}_{2}-\mathrm{MeOH}(9: 1$ and $4: 1)$, respectively. Fractions showing similar TLC profiles were combined resulting into four pools (I-IV).

Pool I (fractions 1-90, $7 \mathrm{~g}$ ) contained mainly fatty acid and waxes and was discarded. Fractions 91-170 constituted pool II (15 g) and was found to contain two major spots which were further purified using medium pressure chromatography (pressure $\approx 1$ bar), eluting with n-hexane-ethyl acetate $(9: 1$ and $4: 1)$ to give stigmasta- 5 , 22-dien-3-acetate $(4,175 \mathrm{mg})$ and 3-acetoxyfriedooleanane (9,95 mg) (Opiyo et al., 2009). Pool III (fractions 171-250, $10 \mathrm{~g}$ ) upon repeated fractionation using n-hexane-ethyl acetate (4:1 and 3:1) yielded spinasta-7, 22-dien-3-ol $(6,75 \mathrm{mg}), 3$-oxofriedooleanane $(7,55 \mathrm{mg})$ and 3hydrox-friedooleanane $(8,165 \mathrm{mg}$ ) (Anjaneyulu and Narayana-Rao, 1980). Pool IV (6.5 g) gave stigmasta-5, 22-dien-3-ol $(5,100 \mathrm{mg})$ and betulinic acid $(10,85 \mathrm{mg})$ (Opiyo et al., 2009).

Isolation and identification of $\mathrm{MeOH}$ extract constituents: The extract (75 g) was pre-adsorbed onto silica gel and chromatographed with $\mathrm{CH}_{2} \mathrm{Cl}_{2}-\mathrm{MeOH}$ gradient to pure $\mathrm{MeOH}$ affording 120 fractions of $50 \mathrm{~mL}$ each. The composition of the fractions were monitored by TLC using $\mathrm{CH}_{2} \mathrm{Cl}_{2}-\mathrm{MeOH}(4: 1,3: 2$ and 1:1) and those that exhibited similar TLC profiles were combined to constitute two major pools (V and VI). Fractions 10-50 (pool V, 12 g) was further purified by chromatography using $\mathrm{CH}_{2} \mathrm{Cl}_{2}-$ $\mathrm{MeOH}(9: 1)$ followed by the same solvent system in the ratio $4: 1$ to give kaempferol $(14,85 \mathrm{mg})$, cyasterone (3, $78 \mathrm{mg})$, quercetin $(12,105 \mathrm{mg})$, myricetin $(13,55 \mathrm{mg})$, 24-ethylcholesta-5, 22E, 25-triene 3-O- $\beta$-glucoside (2, 45 $\mathrm{mg}$ ) and quercetin 3-O- $\beta$-glucoside (11, $105 \mathrm{mg}$ ) (Opiyo et al., 2009; Manguro et al., 2004).

The remaining fractions (pool VI, $3 \mathrm{~g}$ ) contained two major compounds which could not be obtained in pure form and were purified by preparative HPLC using acetonitrile- $\mathrm{H}_{2} \mathrm{O}(35: 65)$ : mobile flow rate $10 \mathrm{~mL} \mathrm{~min}^{-1}$, injecting $10 \mu \mathrm{L}$ each time to afford pure 24-ethylcholesta$5,22 \mathrm{E}, 25$-triene 3 -O- $\beta$-glucoside ( 1 ' $>4$ ') rhamnoside (1) $\left(\mathrm{t}_{\mathrm{r}}=39 \mathrm{~min}, 93 \mathrm{mg}\right.$ ) (Anjaneyulu and Narayana-Rao, 1980).

\section{Antimicrobial assay}

Test microorganisms: Three bacteria and three fungi, all locally isolated microorganisms (LIO) were obtained from
New Nyanza General Hospital in Kisumu, Kenya. The bacterial pathogens were Streptococcus pneumoniae, Staphylococcus aureus (gram positive) and Escherichia coli (gram negative) while the fungal pathogens were Candida albicans (yeast fungus), Trichophyton mentagrophytes and Microsporium gypseum (filamentous fungi). The microorganisms were chosen on the basis of ethnobotanical information available on the plant.

Antibacterial screening: Antibacterial activity of crude extracts and pooled fractions was done using agar well diffusion method (Duguid et al., 1998; Greenspan and Greenspan, 1997). The bacterial isolates were first grown on a nutrient broth (Oxoid) for $24 \mathrm{~h}$ before use. The inoculum suspensions were standardized to $10^{7}-10^{8} \mathrm{CFU} \mathrm{mL}^{-1}$. About 200 microliter of the standard cell suspensions was spread uniformly using a sterile glass spreader on a nutrient agar (Oxiod). Wells were then bored into the agar using a sterile $6 \mathrm{~mm}$ diameter cork borer. Approximately $100 \mu \mathrm{L}$ of crude extracts (at $500 \mu \mathrm{g} \mathrm{mL}^{-1}$ ) and pooled fractions at concentrations of $200 \mu \mathrm{g} \mathrm{mL} \mathrm{m}^{-1}$ were separately introduced into the wells in the culture plates previously seeded with the test organisms, allowed to stand at room temperature for about $1 \mathrm{~h}$ and then incubated at $37^{\circ} \mathrm{C}$ for $24 \mathrm{~h}$. Controls were set up in parallel using Dimethylsulfoxide (DMSO) that was used to reconstitute the extracts. The plates were observed for zones of inhibition after $48 \mathrm{~h}$. The effects of the extracts and pooled fractions were compared with those of chlorophenicol, ofloxacin and streptomycin at a concentration of $10 \mu \mathrm{g} \mathrm{m}^{-1}$ each.

Antifungal screening: The antifungal tests were done according to the known methods (Irobi et al., 1996). The fungal isolates were allowed to grow on a Sabouraud Dextrose Agar (SDA) (Oxoid) at $25^{\circ} \mathrm{C}$ until they sporulated. The fungal spores were standardized before use and 100 microliter of the standardized fungal suspension was evenly spread on the SDA (oxoid) using a glass spreader.

Wells were then bored into the agar media using a sterile $6 \mathrm{~mm}$ cork borer and filled with solutions of crude extracts and pooled fractions at concentrations of 500 and $200 \mu \mathrm{g} \mathrm{mL}^{-1}$, respectively. The plates were allowed to stand for $1 \mathrm{~h}$ for proper diffusion of the extracts and pooled fractions into the media. The plates were incubated at $25^{\circ} \mathrm{C}$ for $72 \mathrm{~h}$ and later observed for zones of inhibition. Controls were set up in parallel using DMSO.

The effect of the extracts on the fungal isolates was compared with fluconazole, cinamizole and amphotericin $\mathrm{B}$ at a concentration of $10 \mu \mathrm{g} \mathrm{mL} \mathrm{m}^{-1}$ each. 
Minimum Inhibitory Concentration (MIC): Minimum Inhibitory Concentration (MIC) of pure isolates was determined using standard procedures (Russeland and Furr, 1977; Igbinosa et al., 2009) whereby the isolates were dissolved in DMSO and different concentrations ranging between 1000-1 $\mu \mathrm{g} \mathrm{mL} \mathrm{m}^{-1}$ were prepared. The MIC was taken as the lowest concentration that prevented the growth of the test microorganism. The antifungal and antibacterial activities were done in four replicates $(n=4)$.

\section{RESULTS AND DISCUSSION}

Phytochemical studies: Chromatographic fractionation of $\mathrm{CH}_{2} \mathrm{Cl}_{2}$ and $\mathrm{MeOH}$ extracts from C. floribunda whole plant afforded 24-ethylcholesta-5, 22E, 25-triene 3-O- $\beta$ glucoside ( 1 ' $\rightarrow$ 4') rhamnoside, 24-ethylcholesta-5, 22E, 25 triene 3-O- $\beta$-glucoside, cyasterone, stigmasta-5, 22-dien-3acetate, stigmasta-5, 22-dien-3-ol, spinasta-7, 22-dien-3-ol, 3-oxofriedooleanane, 3-hydroxfriedooleanane, 3-acetoxyfriedooleanane, betulinic acid, quercetin 3-O- $\beta$-glucoside, quercetin, myricetin, kaempferol (Opiyo et al., 2009; Anjaneyulu and Narayana-Rao, 1980; Manguro et al., 2004).

Antibacterial and antifungal activities of extracts, fractions and pure compounds: Dichloromethane and $\mathrm{MeOH}$ extracts showed activities against all the three bacteria tested in the study (Table 1). The $\mathrm{MeOH}$ extract strongly inhibited the growth of $S$. pneumoniae (16 16.3 ) and $S$. aureus $(16 \pm 0.4)$ while $E$. coli (12 \pm 0.5 ) was moderately inhibited. The $\mathrm{MeOH}$ extract was found to be more active in this respect than the $\mathrm{CH}_{2} \mathrm{Cl}_{2}$. Similarly, in the antifungal tests, methanol extract exhibited

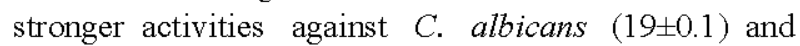
T. mentagrophytes $(16 \pm 1.1)$ than the dichloromethane extract (Table 2).

The $\mathrm{MeOH}$ extract also showed fairly moderate activity against $M$. gypseum $(14 \pm 0.3)$. It can be noted that the bacteria and fungi tested were relatively more susceptible to $\mathrm{MeOH}$ extract than $\mathrm{CH}_{2} \mathrm{Cl}_{2}$.

Fractionation of dichloromethane extract as previously discussed in the experimental section gave four pools (I-IV) which were bioassayed. With the exception of pool $\mathrm{I}$, the remaining three pools displayed moderate and weak activities against bacteria tested (Table 3). Similarly, the methanolic extract upon chromatography with $\mathrm{CH}_{2} \mathrm{Cl}_{2}-\mathrm{MeOH}$ gradient to pure $\mathrm{MeOH}$ constituted pools $\mathrm{V}$ and VI which exhibited similar antibacterial activities against all the bacteria tested (Table 3). In the antifungal tests (Table 4), pool II weakly inhibited the growth of T. mentagrophtes and C. albicans with values of $6 \pm 10$ and $4 \pm 0.2$, respectively. No activity was observed with this pool for $M$. gypseum. Pool III and IV both from $\mathrm{CH}_{2} \mathrm{Cl}_{2}$ extract moderately inhibited the growth of $C$. albicans and T. mentagrophytes but failed to show any activity against $M$. gypseum. Similarly, fairly strong inhibitions were experienced with pools $\mathrm{V}$ and VI against $C$. albicans and $T$. mentagrophytes, however against $M$. gypseum the pools showed moderate activities. The two pools which were from $\mathrm{MeOH}$ extracts were better fungal growth inhibitors than those from $\mathrm{CH}_{2} \mathrm{Cl}_{2}$ extract.

In the determination of MIC (Table 5), out of the fourteen compounds isolated from $C$. floribunda only four showed activities against the tested pathogens. Although, pool II showed weak activities against $S$. aureus, C. albicans and T. mentagrophytes, these activities were not observed with the pure compounds 4 and 9 isolated from this pool. Compounds 2 from $\mathrm{MeOH}$ extract showed $\mathrm{MIC}$ value of $50 \mu \mathrm{g} \mathrm{mL}^{-1}$ against both $S$. pneumoniae and $S$. aureus while for E.coli it gave a value $>100 \mu \mathrm{g} \mathrm{mL}^{-1}$. Similarly, the compound exhibited $\mathrm{MIC}$ value of $25 \mu \mathrm{g} \mathrm{mL} \mathrm{m}^{-1}$ for C. albicans but values of 50 and $100 \mu \mathrm{g} \mathrm{mL} \mathrm{mL}^{-1}$ were observed for T. mentagrophytes and $M$. gypseum, respectively. On the other hand,

Table 1: Antibacterial activity of C. floribunda $\mathrm{CH}_{2} \mathrm{Cl}_{2}$ and $\mathrm{MeOH}$ extracts Zone of growth inhibition in $\mathrm{mm}$ (mean $\pm \mathrm{SD}$ )

\begin{tabular}{llcccc} 
& $\mathrm{CH}_{2} \mathrm{Cl}_{2}$ & $\mathrm{MeOH}$ & Oflaxacin & Chlorophenicol & Streptomycin \\
\hline S. pneumoniae & $14 \pm 0.2$ & $16 \pm 0.3$ & $25 \pm 0.1$ & $27 \pm 0.1$ & $22 \pm 1.0$ \\
S. aureus & $12 \pm 0.6$ & $16 \pm 0.4$ & $28 \pm 0.5$ & $28 \pm 0.4$ & $20 \pm 0.3$ \\
E. coli & $8 \pm 0.8$ & $12 \pm 0.5$ & $25 \pm 0.16$ & $19 \pm 0.5$ & $0 \pm 0$ \\
\hline
\end{tabular}

Table 2: Antifungal activity of $C$. floribunda $\mathrm{CH}_{2} \mathrm{Cl}_{2}$ and $\mathrm{MeOH}$ extracts Zone of growth inhibition in $\mathrm{mm}($ mean $\pm \mathrm{SD})$

\begin{tabular}{lllrcc} 
& $\mathrm{CH}_{2} \mathrm{Cl}_{2}$ & $\mathrm{MeOH}$ & Micanazole & Amphotericin B & Fluoonazole \\
C. albicans & $16 \pm 1.0$ & $19 \pm 0.1$ & $29 \pm 1.0$ & $32 \pm 1.1$ & $29 \pm 1.2$ \\
T. mentagrophytes & $14 \pm 0.5$ & $16 \pm 1.1$ & $22 \pm 0.2$ & $29 \pm 0.4$ & $20 \pm 0$ \\
M. gypseum & $10 \pm 0$ & $14 \pm 0.3$ & $24 \pm 0.6$ & $26 \pm 0.1$ & $21 \pm 1.0$ \\
\hline
\end{tabular}

Table 3: Antibacterial activity of C. floribunda $\mathrm{CH}_{2} \mathrm{Cl}_{2}$ and $\mathrm{MeOH}$ extract fractions

\begin{tabular}{|c|c|c|c|c|c|c|}
\hline \multirow[b]{3}{*}{ Bacteria } & \multicolumn{6}{|c|}{ Zone of growth inhibition in $\mathrm{mm}($ mean $\pm \mathrm{SD})$} \\
\hline & \multicolumn{3}{|c|}{$\mathrm{CH}_{2} \mathrm{Cl}_{2}$ fractions } & \multicolumn{3}{|c|}{$\mathrm{MeOH}$ fractions } \\
\hline & Pool I & Pool II & Pool III & Pool TV & Pool V & Pool VI \\
\hline S.pneumoniae & $0 \pm 0$ & $0 \pm 0$ & $10 \pm 0.3$ & $12 \pm 0.5$ & $14 \pm 0.1$ & $14 \pm 0.2$ \\
\hline S. aureus & $0 \pm 0$ & $4 \pm 0.5$ & $12 \pm 0.4$ & $12 \pm 0$ & $14 \pm 0.2$ & $14 \pm 0.3$ \\
\hline E.coli & $0 \pm 0$ & $0 \pm 0$ & $4 \pm 0.6$ & $6 \pm 03$ & $10 \pm 0.3$ & $10 \pm 1.2$ \\
\hline
\end{tabular}

Table 4: Antifungal activities of $C$. floribunda $\mathrm{CH}_{2} \mathrm{Cl}_{2}$ and $\mathrm{MeOH}$ fractions Zone of growth inhibition in $\mathrm{mm}$ (mean $\pm \mathrm{SD}$ )

\begin{tabular}{|c|c|c|c|c|c|c|}
\hline \multirow[b]{3}{*}{ Fungi } & \multicolumn{6}{|c|}{ Zone of growth inhibition in $\mathrm{mm}($ mean $\pm \mathrm{SD})$} \\
\hline & \multicolumn{3}{|c|}{$\mathrm{CH}_{2} \mathrm{Cl}_{2}$ fractions } & \multicolumn{3}{|c|}{$\mathrm{MeOH}$ fractions } \\
\hline & Pool I & Pool II & Pool III & Pool IV & Pool V & Pool VI \\
\hline C. albicans & $0 \pm 0$ & $4 \pm 0.2$ & $12 \pm 0.3$ & $14 \pm 0.1$ & $16 \pm 0.2$ & $16 \pm 0.5$ \\
\hline T. mentagrophytes & $0 \pm 0$ & $6 \pm 1.0$ & $12 \pm 0.6$ & $12 \pm 0.3$ & $14 \pm 0.1$ & $14 \pm 1.3$ \\
\hline M. gypseum & $0 \pm 0$ & $0 \pm 0$ & $0 \pm 0$ & $0 \pm 0$ & $14 \pm 1.0$ & $12 \pm 1.2$ \\
\hline
\end{tabular}


Res. J. Pharmacol., 4 (3): 55-59, 2010

Table 5: Mnimum inhibitory concentration $\left(\mathrm{MIC}, \mu \mathrm{g} \mathrm{mL}^{-1}\right)$ of pure compounds and standard antibiotics

\begin{tabular}{|c|c|c|c|c|c|c|}
\hline \multirow[b]{2}{*}{ Cmpound/antibiotic } & \multicolumn{3}{|l|}{ Bacteria } & \multicolumn{3}{|l|}{ Fungi } \\
\hline & S. pneumonice & S. cureus & E. coil & C.albicans & T. mentagrophytes & $M$ gypseum \\
\hline$\overline{2}$ & 50 & 50 & $>100$ & 25 & 50 & 100 \\
\hline 3 & 50 & 50 & 100 & 25 & 50 & 50 \\
\hline 7 & 100 & 100 & $>200$ & 100 & 100 & $>200$ \\
\hline 10 & 100 & 100 & $>200$ & 50 & 100 & 100 \\
\hline Chorophenicol & 6.25 & 3 & 1.5 & ND & ND & $\mathrm{ND}$ \\
\hline Ofloxacin & 6.25 & 6.25 & 3 & ND & ND & ND \\
\hline Streptomycin & 12.5 & 6.25 & ND & $\mathrm{ND}$ & ND & ND \\
\hline Micanazole & ND & $\mathrm{ND}$ & ND & 6.25 & 6.25 & 3 \\
\hline Amphoterecin B & $\mathrm{ND}$ & ND & ND & 6.25 & 3 & 6.25 \\
\hline Fluconazole & ND & $\mathrm{ND}$ & ND & 12.5 & 12.5 & 6.25 \\
\hline
\end{tabular}

$\mathrm{ND}=$ Not Detected

compound 3 inhibited the growth of both $S$. pneumoniae and $S$. aureus by showing a MIC value $50 \mu \mathrm{g} \mathrm{mL}^{-1}$ while the value for $E$. coli was $100 \mu \mathrm{g} \mathrm{mL} \mathrm{m}^{-1}$. The same compound gave $\mathrm{MIC}$ value of $25 \mu \mathrm{g} \mathrm{mL} \mathrm{m}^{-1}$ against C. albicans and $50 \mu \mathrm{g} \mathrm{mL} \mathrm{m}^{-1}$ for both $T$. mentagrophytes and $M$. gypseum. The other compound that showed slight activity was 7 which gave $\mathrm{MLC}$ value of $100 \mu \mathrm{g} \mathrm{mL}-1$ against both $S$. aureus and $S$. pneumoniae and almost no activity against $E$. coli $\left(>200 \mu \mathrm{g} \mathrm{mL}^{-1}\right)$. Similarly, the same compound was observed to be active against $C$. albicans and T. mentagrophytes with $\mathrm{MIC}$ value of $100 \mu \mathrm{g} \mathrm{mL}-1$ but not active against $M$. gypseum. Compound 10 isolated from $\mathrm{CH}_{2} \mathrm{Cl}_{2}$ showed MIC value of $100 \mu \mathrm{g} \mathrm{mL} \mathrm{m}^{-1}$ for both $S$. pneumoniae and $S$. aureus and $<200 \mu \mathrm{g} \mathrm{mL}^{-1}$ for $E$. coli. In the antifungal tests, it was found to be active against $C$. albicans with $\mathrm{MLC}$ value of $50 \mu \mathrm{g} \mathrm{mL}^{-1}$ and moderately active against $T$. mentagrophytes $(100 \mu \mathrm{g}$ $\mathrm{mL}^{-1}$ ) but inactive against $M$. gypseum.

The study showed that extracts from C. floribunda have antifungal and antibacterial activities and this is probably why the plant is widely used in traditional medicine. The extracts from the plant have broad spectrum activity since they are effective against both gram positive and gram negative bacteria. The extracts were also active against dermatophytic fungi, T. mentagrophytes and $M$. gypseum. This observation is of particular interest since many Kenyan traditional healers use the plant for treating ringworm, a type of infection caused by the two fungi above. The extracts were also found to be active against $C$. albicans, a ubiquitous fungi associated with the pathogenesis of urinary tract infections and oral thrush (Akinpelu and Kolawole, 2004; Widodo et al., 2008). Methanol extract exhibited higher activity compared to dichloromethane and this could be attributed to the fact that antibacterial and antifungal compounds in C. floribunda are polar compounds which could be extracted with polar solvents such as methanol and water.

The antibacterial and antifungal principles from C. floribunda were identified as (24S)-ethylcholesta-
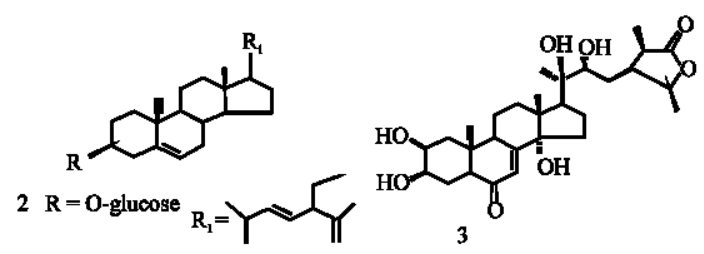

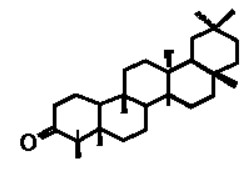

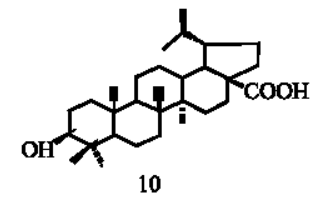

Fig. 1: The antibacterial and antifungal principals from C. floribunda

5,22E, 25-trienene 3-O-glucopyranoside (2), cyasterone (3), 3-oxofriedooleanane (7) and betulinic acid (10) (Fig. 1). Compounds 2 and 3 both from $\mathrm{MeOH}$ extract showed both antibacterial and antifungal activities and were more effective than the latter two. This observation suggests that the antifungal principles in the plant have broad spectrum antifungal activities.

\section{CONCLUSION}

The extracts and pure compounds from the plant were however, less active compared to ofloxacin, chlorophenicol and streptomycin which are known antibacterial compounds. Similarly for the antifungal tests, the extracts and pure compounds were less effective compared with known antifungal drugs such as amphotericin B, micanazole and fluconazole.

\section{ACKNOWLEDGEMENTS}

The researchers are thankful to Kenya Medical Research Institute (KEMRI), Kisumu, Kenya for the use of their laboratory to perform the biological activity tests. Mr. Mathenge of Botany Department, Nairobi University 
is highly thanked for identification of the plant. Dr. Serem of Maseno University clinic is acknowledged for the identification of the bacteria and fungi.

\section{REFERENCES}

Agnew, A.D.Q. and S. Agnew, 1994. Kenya Upland Wild Flowers. 2nd Edn., East African Natural History Society, Nairobi, Kenya, pp: 169.

Ahmed, V.U., R. Khartoon, T.A. Farooqui, N. Ismail and K. Fizza, 1992. Two new eudesmane sesquiterpenes from Pluchea arguta. Nat. Prod. Lett., 1: 225-229.

Akinpelu, D.A. and D.O. Kolawole, 2004. Phytochemical and antimicrobial activity of leaf extract of Piliostigma thionningii (Schum). Sci. Focus, 7: 64-70.

Anjaneyulu, A.S.R. and M. Narayana-Rao, 1980. Elaeodendrol and elaeodendradiol: A new nortriterpenes from Elaedendron glaucum. Phytochemistry, 19: 1163-1169.

Bohlmann, F. and P. Wagner, 1982. Three diterpenes from Conyza podocephala. Phytochemistry, 21: 1693-1695.

Calzada, F., R. Cedillo-Rivera and R. Mata, 2001. Antiprotozoal activity of the constituents of Conyza filaginoides. J. Nat. Prod., 64: 671-673.

De las Heras, B., K. Slowing, J. Benedi, E. Carretero and T. Ortega et al., 1998. Anti-inflammatory and antioxidant activity of plants used in traditional medicine in ecuador. J. Ethnopharmacol., 61: 161-166.

Duguid, J.P., B.P. Marmion and R.H.A. Swain, 1998. Medical Microbiology. Churchill Livingstone, London, UK.

Greenspan, J.S. and D. Greenspan, 1997. Oral Complications in HIV Infections. In: The Medical Management of AIDS, Sande, M.A. and P.A. Volberding (Eds.). Saunders Construction Inc., London, pp: 169-180.

Igbinosa, O.O., E.O. Igbinosia and O. Aiyegoro, 2009. Antimicrobial activity and phytochemical screening of stem bark extract from Jatropha curcas (Linn). Afr. J. Pharm. Pharmacol., 3: 58-62.
Irobi, O.N., M. Moo-Young and W.A. Anderson, 1996. Antimicrobial activity of Annatto (Bixa orellana) extract. Int. J. Pharmacog., 34: 87-90.

Kokwako, J.O., 1976. Medicinal Plants of East Africa. East African Literature Bureau Kampala, Nairobi pp: 62.

Manguro, L.O.A., I. Ugi and P. Lemmen, 2004. Flavonol glycosides of Embelia schimperi leaves. Bull. Chem. Soc. Ethiop., 18: 51-57.

Mata, R., A. Rojas, L. Acevedo, S. Estrada and F. Calzada et al., 1997. Smooth muscle relaxing flavonoids and terpenoids from Conyza filaginoides. Planta Med., 63: 31-35.

Opiyo, S.A., J.A. Ogur, L.O.A. Manguro, L.F. Tietze and H. Schuster, 2009. A new sterol diglycoside from Conyza floribunda: Research article. South Afr. J. Chem., 62: 163-167.

Pandey, C.U., K. Ashok, A.K. Singhal, C. Nabin and C.N. Barua et al., 1984. Stereochemistry of strictic acid and related furano-diterpenes from Conyza japonica and Grangea maderasptana. Phytochemistry, 23: 391-397.

Picciaroni, A.D., L.A. Espinar, G. Ciccia, E. Mongelli, A. Ramano and G.L. Silva, 2000. Bioactive constituents of Conyza albida. Planta Med., 66: 720-723.

Russeland, A.D. and J.R. Furr, 1977. Antibcterial activity of a new chloroxylenol preparation containing ethylenediamine tetraacetic acid. J. Applied Bacteriol., 43: 253-260.

Widodo, G.P., E.Y. Sukandar, Sukrasno and I.K. Adnyana, 2008. A coumarin from ageratum leaves (Ageratum conyzoides L.). Int. J. Pharmacol., 4: 56-59.

$\mathrm{Xu}, 1 ., \mathrm{D}$. Gou, J. Liu, D. Min, S. Wang, Z. Zhang and K. Zheng, 1998. Chemical constituents of Conyza blinni. Zhongguo Hung Yahoo Zazhi, 23: 552-553.

Zdero, C., F. Bohlmann and G.M. Mungai, 1990. Secoclerodanes and other diterpenes from Conyza welwitschii. Phytochemistry, 29: 2247-2252. 